\title{
ELECTRON TRANSPORT IN MODULATION-DOPED InAlAs/InGaAs/InAlAs AND AlGaAs/InGaAs/AlGaAs HETEROSTRUCTURES
}

\author{
J. Požela ${ }^{a}$, K. Požela ${ }^{\text {a }}$, V. Jucienè a, A. Sužiedèlis ${ }^{\text {a }}$, N. Žurauskiené ${ }^{\text {a }}$, and A. S. Shkolnik ${ }^{\text {b }}$ \\ a Semiconductor Physics Institute, Center for Physical Sciences and Technology, A. Goštauto 11, LT-01108 \\ Vilnius, Lithuania \\ E-mail:pozela@pfi.lt \\ b Innolume GmbH, Konrad-Adenauer-Allee 11, 44263 Dortmund, Germany
}

Received 14 June 2011; revised 3 Nonember 2011; accepted 1 December 2011

\begin{abstract}
The possibilities of enhancing the electron mobility and high-field drift velocity in channels of modulation-doped InAlAs/InGaAs and AlGaAs/InGaAs quantum wells by tuning interaction of electrons with interface phonons are tested and reviewed. A large increase in the mobility is achieved in a novel metamorphic $\mathrm{In}_{0.7} \mathrm{Al}_{0.3} \mathrm{As} / \mathrm{In}_{0.8} \mathrm{Ga}_{0.2} \mathrm{As}$ structure with the high InAs content in the InAlAs barrier layer as well as in the $\mathrm{Al}_{x} \mathrm{Ga}_{1-x} \mathrm{As} / \mathrm{In}_{0.2} \mathrm{Ga}_{0.8} \mathrm{As}$ structure with the low AlAs content in the AlGaAs barrier layer. An enhancement in the electron mobility by inserting thin InAs layers into the $\operatorname{In}_{0.52} \mathrm{Al}_{0.48} \mathrm{As} / \mathrm{In}_{0.53} \mathrm{Ga}_{0.47}$ As quantum well is obtained. The electron drift velocity saturates at high electric fields of $1.5-5 \mathrm{kV} / \mathrm{cm}$ and achieves a maximal value of $2.5 \cdot 10^{7} \mathrm{~cm} / \mathrm{s}$ in the InGaAs quantum well with the thin InAs and GaAs inserts.
\end{abstract}

Keywords: electron transport, electron-phonon scattering, InAlAs/InGaAs/InAlAs heterostructures, $\mathrm{AlGaAs} / \mathrm{InGaAs} / \mathrm{AlGaAs}$ heterostructures

PACS: 72.20.Ht, 72.10.Di, 73.40.Kp, 73.63.Hs

\section{Introduction}

The engineering of electron interaction with polar optical (PO) and interface (IF) phonons by inserting thin semiconductor layers into a quantum well (QW), which could reflect PO and IF phonons, is a functional tool for controlling electron transport and photoelectric properties of semiconductor heterostructures [1-15]. In particular, it is essential to increase electron mobility in $\operatorname{In}_{0.52} \mathrm{Al}_{0.48} \mathrm{As} /$ $\mathrm{In}_{0.53} \mathrm{Ga}_{0.47} \mathrm{As} / \mathrm{In}_{0.52} \mathrm{Al}_{0.48} \mathrm{As}$ channels of high electron mobility transistors (HEMTs) that in turn are the basic elements of microwave electronics in the frequency range up to $100 \mathrm{GHz}$, and are intended for detection and generation of electromagnetic radiation in the terahertz frequency range [16-19].

In a modulation-doped structure, the spatial separation of free electrons from an impurity-doped layer reduces impurity scattering; however, it enhances electron scattering by IF phonons in narrow QWs. Due to the spatial separation of the positively charged ionized impurity layer from free electrons in a QW layer, a large $\left(\sim 10^{5} \mathrm{~V} / \mathrm{cm}\right)$ electric field $F_{\perp}$ perpendicular to a QW plane is created. The field $F_{\perp}$ collects free electrons in the QW at the interface barrier, and electron interaction with IF phonons increases. In modulation-doped InAlAs/InGaAs structures at $300 \mathrm{~K}$, electron scattering by IF phonons is a dominant scattering mechanism $[12,14,15]$.

In this work, we report on the experimental study of the possibilities to increase electron mobility and high-field drift velocity in the modulation-doped InAlAs/InGaAs and AlGaAs/InGaAs QW channels by using the following two tools for controlling electron scattering by $\mathrm{PO}$ and IF phonons: (i) tuning the electron scattering by IF phonons by choosing the InAs and AlAs contents in the barrier ternary alloys of $\operatorname{In}_{x} \mathrm{Al}_{1-x} \mathrm{As} / \mathrm{In}_{y} \mathrm{Ga}_{1-y}$ As and $\mathrm{Al}_{x} \mathrm{Ga}_{1-x} \mathrm{As} / \mathrm{In}_{y} \mathrm{Ga}_{1-y}$ As heterostructures; (ii) changing the electron scattering by confined $\mathrm{PO}$ and IF phonons inserting thin InAs layers $(1-3 \mathrm{~nm}$ ) into the $\operatorname{In}_{0.52} \mathrm{Al}_{0.48} \mathrm{As} / \mathrm{In}_{0.53} \mathrm{Ga}_{0.47} \mathrm{As} \mathrm{QW}$. The thin 
electron-transparent InAs insert is assumed to be reflecting for PO and IF phonons, i. e. considered as a phonon wall $[3,5]$.

\section{Regulation of electron-interface phonon scatte- ring rate by changing composition of $\operatorname{In}_{x} A 1_{1-x} A s /$ In $\mathrm{Ga}_{1-y} \mathrm{As}$ and $\mathrm{Al} \mathrm{Ga}_{1-x} \mathrm{As} / \mathrm{In}_{y} \mathrm{Ga}_{1-y} \mathrm{As} \mathrm{QWs}$}

An electron-IF phonon scattering rate is a function of IF phonon frequencies, which are determined by a composition of interface semiconductor materials. Calculations of the electron-IF phonon scattering rate show that the rate can be reduced several times by increasing InAs content $x$ in the $\operatorname{In}_{x} \mathrm{Al}_{1-x} \mathrm{As}$ barrier layer at the $\operatorname{In}_{0.53} \mathrm{Ga}_{0.47} \mathrm{As} \mathrm{QW}$, as well as by decreasing AlAs content $x$ in the $\mathrm{Al}_{x} \mathrm{Ga}_{1-x}$ As barrier layer at the $\operatorname{In}_{0.2} \mathrm{Ga}_{0.8}$ As QW $[12,14,15]$. The maximal decrease of the electron-IF phonon scattering rate is achieved for InAs content $x$ around 0.8 [11] and AlAs content $x=0$ [14].

The possibilities to increase the electron mobility by decreasing the electron-IF phonon scattering rate in the HEMT structures were experimentally investigated in four types of heterostructures: $\mathrm{In}_{0.2} \mathrm{Al}_{0.8} \mathrm{As} / \mathrm{In}_{0.2} \mathrm{Ga}_{0.8} \mathrm{As}$ and $\mathrm{GaAs} / \mathrm{In}_{0.2} \mathrm{Ga}_{0.8} \mathrm{As}$ with QW thickness of $12 \mathrm{~nm}$, and $\operatorname{In}_{0.52} \mathrm{Al}_{0.48} \mathrm{As} /$ $\mathrm{In}_{0.53} \mathrm{Ga}_{0.47} \mathrm{As}$ and $\mathrm{In}_{0.7} \mathrm{Al}_{0.3} \mathrm{As} / \mathrm{In}_{0.8} \mathrm{Ga}_{0.2}$ As with QW thickness of $16 \mathrm{~nm}$.

The In $\mathrm{Al}_{1-x} \mathrm{As} / \mathrm{In}_{y} \mathrm{Ga}_{1-y}$ As heterostructures with a different $x$ in the barrier layer, $x=0.52$ and $x=0.7$, were grown by molecular beam epitaxy on InP substrates. The growth of the structure with increased InAs content $x=0.7$ in the barrier was performed on the metamorphic buffer. This technique allowed us to increase InAs content $y=0.8$ in the QW layer. The latter layer was grown pseudomorphically stressed.

The calculations of the electron scattering rate by IF phonons predict that the mobility enhance- ment at $300 \mathrm{~K}$ in the $\operatorname{In}_{0.7} \mathrm{Al}_{0.3} \mathrm{As} / \mathrm{In}_{0.8} \mathrm{Ga}_{0.2} \mathrm{As} \mathrm{QW}$ is just about twice in comparison to that in the $\mathrm{In}_{0.52} \mathrm{Al}_{0.48} \mathrm{As} / \mathrm{In}_{0.53} \mathrm{Ga}_{0.47} \mathrm{As} \mathrm{QW}$.

Experimental measurements of electron Hall mobility in the grown novel $\mathrm{In}_{0.7} \mathrm{Al}_{0.3} \mathrm{As} / \mathrm{In}_{0.8} \mathrm{Ga}_{0.2} \mathrm{As}$ and the conventional HEMT $\operatorname{In}_{0.52} \mathrm{Al}_{0.48} \mathrm{As} /$ $\mathrm{In}_{0.53} \mathrm{Ga}_{0.47} \mathrm{As}$ heterostructures confirm this large increase in the electron mobility with the increased InAs content in the barrier and QW layers (see Table 1). The measured electron mobility and sheet electron density in the conventional HEMT In ${ }_{0.52} \mathrm{Al}_{0.48} \mathrm{As} / \mathrm{In}_{0.53} \mathrm{Ga}_{0.47}$ As structures were $\mu_{\mathrm{H}}=6.2 \cdot 10^{3} \mathrm{~cm}^{2} \mathrm{~V}^{-1} \mathrm{~s}^{-1}$ and $n_{\mathrm{s} 0}=1.0 \cdot 10^{12} \mathrm{~cm}^{-2}$ at room temperature. While in the novel $\operatorname{In}_{0.7} \mathrm{Al}_{0.3} \mathrm{As} /$ $\mathrm{In}_{0.8} \mathrm{Ga}_{0.2}$ As structures (named as high electron mobility (HEM) structures), $\mu_{\mathrm{H}}$ and $n_{\mathrm{s} 0}$ achieve the values of $12.3 \cdot 10^{3} \mathrm{~cm}^{2} \mathrm{~V}^{-1} \mathrm{~s}^{-1}$ and $1.4 \cdot 10^{12} \mathrm{~cm}^{-2}$, respectively. It is worth to note that at $77 \mathrm{~K}$, the electron mobility and density in HEM structures were $\mu_{\mathrm{H}}=50.5 \cdot 10^{3} \mathrm{~cm}^{2} \mathrm{~V}^{-1} \mathrm{~s}^{-1}$ and $n_{\mathrm{s} 0}=1.3 \cdot 10^{12} \mathrm{~cm}^{-2}$.

In the $\mathrm{Al}_{x} \mathrm{Ga}_{1-x} \mathrm{As} / \mathrm{In}_{0.2} \mathrm{Ga}_{0.8} \mathrm{As} \mathrm{QW}$, the increase of the measured mobility is explained by a large decrease of the electron-IF phonon scattering rate in the heterostructure when the $\mathrm{Al}$ content $x=0.3$ is changed by $x=0$ [14]. The measured parameters of the structures are shown in Table 1.

Thus, for the first time, the largest increase in the electron mobility in the modulationdoped AlGaAs/InGaAs and InAlAs/InGaAs QWs is obtained by choosing the composition of both AlGaAs and InAlAs barriers and InGaAs QW layers. Note that the mobility value of $12.3 \times 10^{3} \mathrm{~cm}^{2} \mathrm{~V}^{-1} \mathrm{~s}^{-1}$ achieved in the $\mathrm{In}_{0.7} \mathrm{Al}_{0.3} \mathrm{As} /$ $\mathrm{In}_{0.8} \mathrm{Ga}_{0.2}$ As structure is among the best ones ever reported for InAlAs/InGaAs heterostructures $\left[\mu=(10-16) \cdot 10^{3} \mathrm{~cm}^{2} \mathrm{~V}^{-1} \mathrm{~s}^{-1}\right]$ at $300 \mathrm{~K}[20-22]$. It is worth to note that the highest mobility values are obtained in the InAlAs/InGaAs heterostructure for In content $x=0.75$ at the interface [20],

Table 1 . The Hall mobility $\mu_{\mathrm{H}}$ and electron density $n_{\mathrm{s} 0}$ at $300 \mathrm{~K}$ in the samples with different InAs content $x$ in the $\mathrm{In}_{\mathrm{x}} \mathrm{Al}_{1-\mathrm{x}} \mathrm{As} / \mathrm{In}_{y} \mathrm{Ga}_{1-y} \mathrm{As}(\mathrm{HEM}$ and $B)$ and $\mathrm{AlAs}$ content in the $\mathrm{Al}_{x} \mathrm{Ga}_{1-x} \mathrm{As}_{\mathrm{S}} / \mathrm{In}_{0.2} \mathrm{Ga}_{0.8} \mathrm{As}_{\text {seterostructures }}(C$ and $D)$. $v_{\text {sat }}$ is the saturated drift velocity. Error value of the presented parameters does not exceed $10 \%$.

\begin{tabular}{c|cc|cc}
\hline Sample & Heterointerface composition & $\mu_{\mathrm{H}}, 10^{3} \mathrm{~cm}^{2} \mathrm{~V}^{-1} \mathrm{~s}^{-1}$ & $n_{\mathrm{s0}}, 10^{12} \mathrm{~cm}^{-2}$ & $v_{\text {sat }}, 10^{7} \mathrm{~cm} \mathrm{~s}^{-1}$ \\
\hline $\mathrm{HEM}$ & $\mathrm{In}_{0.7} \mathrm{Al}_{0.3} \mathrm{As} / \mathrm{In}_{0.8} \mathrm{Ga}_{0.2} \mathrm{As}$ & 12.3 & 1.4 & 1.7 \\
\hline$B$ & $\mathrm{In}_{0.52} \mathrm{Al}_{0.48} \mathrm{As} / \mathrm{In}_{0.53} \mathrm{Ga}_{0.47} \mathrm{As}$ & 6.2 & 1.0 & 2.5 \\
\hline$C$ & $\mathrm{GaAs}_{\mathrm{In}} \mathrm{In}_{0.2} \mathrm{Ga}_{0.8} \mathrm{As}$ & 6.4 & 2.0 & 1.5 \\
\hline$D$ & $\mathrm{Al}_{0.15} \mathrm{Ga}_{0.85} \mathrm{As} / \mathrm{In}_{0.2} \mathrm{Ga}_{0.8} \mathrm{As}$ & 5.0 & 2.9 & 0.7 \\
\hline
\end{tabular}


which coincide with the theoretical estimation of the minimal electron-IF phonon scattering rate $[6,11]$. Therefore, the mobility increase observed in Refs. [20-22] at $300 \mathrm{~K}$ can be explained by the decrease of electron-IF phonon scattering rate, when In content $x$ increases up to $x=0.75$.

\section{Insertion of InAs phonon walls into the InGaAs QW}

The other possibility of increasing the electron mobility in a modulation-doped structure is the insertion of thin InAs layers - phonon walls into the InGaAs QW $[3,5,11,12]$.

Experimental study of the possibility of suppressing the electron-PO and -IF phonon scattering rates and, hence, increasing the electron mobility by inserting InAs phonon walls into the InGaAs QW was performed with four structures.
The layer composition of two pair samples ( $A, A 1$ and $B, B 1)$ is presented in Fig. 1 . The structures without the InAs inserts and with them are labelled by $A, B$ and $A 1, B 1$, respectively. The GaAs thin layers $(1.1 \mathrm{~nm})$ in samples $B$ and $B 1$ additionally serve for the phonon confinement in the QW.

The measured electron Hall mobility and electron density $n_{\mathrm{s} 0}$ at room temperature in the grown heterostructures are listed in Table 2 . The mobility in sample $B 1$ with two InAs inserts, and in sample $A 1$ with a single InAs insert is larger than in samples $A$ and $B$ without the inserts by factors 1.35 (for $B, B 1$ pair) and 1.11 (for $A, A 1$ pair).

Thus, the additional increase in the electron mobility in the modulation-doped structures due to insertion of thin InAs phonon walls into the $\mathrm{In}_{0.52} \mathrm{Al}_{0.48} \mathrm{As} / \mathrm{In}_{0.53} \mathrm{Ga}_{0.47} \mathrm{As} \mathrm{QW}$ is experimentally confirmed.

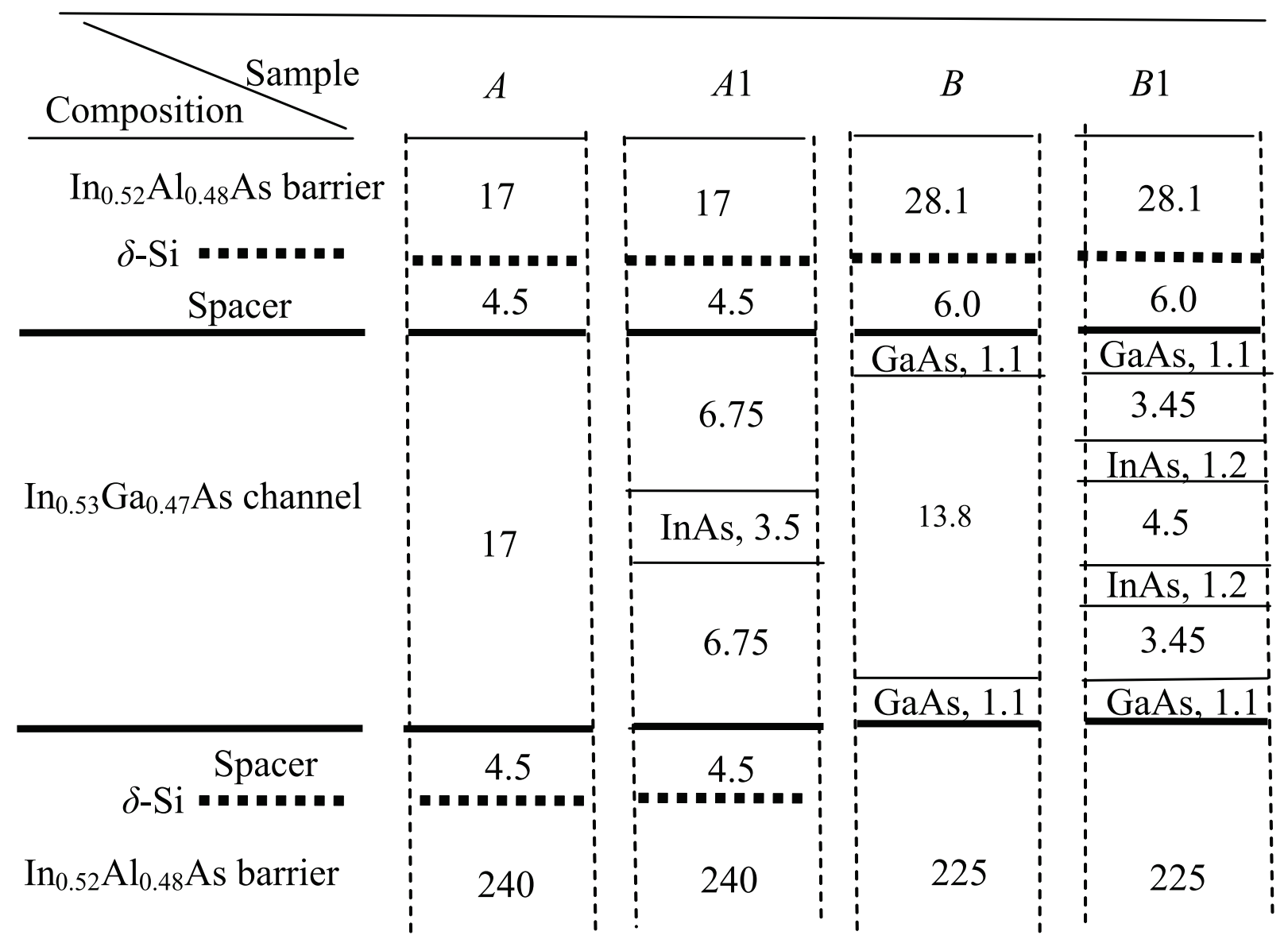

Fig. 1. Schematic representation of the $\operatorname{In}_{0.52} \mathrm{Al}_{0.48} \mathrm{As} / \mathrm{In}_{0.53} \mathrm{Ga}_{0.47} \mathrm{As} / \mathrm{In}_{0.52} \mathrm{Al}_{0.48} \mathrm{As}$ structures with the thin InAs and GaAs inserts in the $\mathrm{In}_{0.53} \mathrm{Ga}_{0.47}$ As QWs. The layer composition and thicknesses (in $\mathrm{nm}$ ) are indicated. 
Table 2. Hall mobility $\mu_{\mathrm{H}}$ and electron sheet density $n_{\mathrm{s} 0}$ in comparison with mobility $\mu_{B}$ and density $n_{\mathrm{s} B}$ obtained from magnetoresistance measurements of the samples with $\operatorname{In}_{0.53} \mathrm{Ga}_{0.47}$ As QW at $300 \mathrm{~K} . v_{\text {sat }}$ is the maximal (saturated) drift velocity. Error value of the presented parameters does not exceed $10 \%$.

\begin{tabular}{c|c|c|c|c|c}
\hline Sample no. & $\mu_{\mathrm{H}}, 10^{3} \mathrm{~cm}^{2} \mathrm{~V}^{-1} \mathrm{~s}^{-1}$ & $n_{\mathrm{s} 0}, 10^{12} \mathrm{~cm}^{-2}$ & $\mu_{B}, 10^{3} \mathrm{~cm}^{2} \mathrm{~V}^{-1} \mathrm{~s}^{-1}$ & $n_{\mathrm{s} B}, 10^{12} \mathrm{~cm}^{-2}$ & $v_{\text {sat }}, 10^{7} \mathrm{~cm} \mathrm{~s}^{-1}$ \\
\hline$B 1$ & 8.4 & 1.2 & 8.3 & 1.5 & 2.5 \\
\hline$A 1$ & 6.1 & 2.5 & 6.1 & 2.6 & 1.9 \\
\hline$B$ & 6.2 & 1.0 & 6.5 & 1.4 & 2.5 \\
\hline$A$ & 5.5 & 3.5 & 5.9 & 3.2 & 1.5 \\
\hline
\end{tabular}

\section{High-field electron drift velocity}

A large mobility increase coincides with the predicted decrease in the electron-IF phonon scattering rate in the InGaAs QW channels with the inserted InAs barriers [3, 5, 11, 12]. However, the IF phonon scattering rate increases by one order, when the electron energy exceeds the IF phonon energy $(30-50 \mathrm{meV})[5,12,14]$. Hence, a large increase in the scattering rate and, therefore, a large decrease in the mobility due to electron heating by electric field can be predicted.

The field dependence of the QW channel conductivity was determined from the measured dependences of the current $I_{\mathrm{D}}$ through the channel on the applied voltage $V_{\mathrm{D}}$. The voltage pulses of $80 \mathrm{~ns}$ duration were used. The measurements were performed on the samples in the form of gateless mesa structures, $100 \mu \mathrm{m}$ wide, with deposited $100 \times 100 \mu \mathrm{m}^{2} \mathrm{Au} / \mathrm{Ni} / \mathrm{Ge}$ ohmic contacts onto the samples. The length of the samples (a distance between ohmic contacts) was $d=10 \mu \mathrm{m}$.

The dependences of the experimentally observed source-drain current on the mean electric field strength along the channel of length $d, F_{\mathrm{D}}=V_{\mathrm{D}} / d$, where $V_{\mathrm{D}}$ is the applied source-drain voltage, are presented in Figs. 2 and 3. One can see very specific peculiarities in the observed electric field dependences of the current in the modulation-doped structures. The current sub-linearity and saturation are observed at field $F=2-4 \mathrm{kV} / \mathrm{cm}$, which is significantly less than the threshold field $F_{\text {th }}$ for current oscillations due to negative electron conductivity (Gunn effect).

In order to separate the contribution of the electron drift velocity to the current along the QW channel, the field dependence of the electron mobility $\mu_{B}$ and density $n_{\mathrm{s} B}$ were determined from geometric $\left(\boldsymbol{B}_{0} \boldsymbol{I}_{\mathrm{D}}\right)$ magnetoresistance measurements at magnetic field $B=1 \mathrm{~T}$ in the short $(10 \mu \mathrm{m})$ and

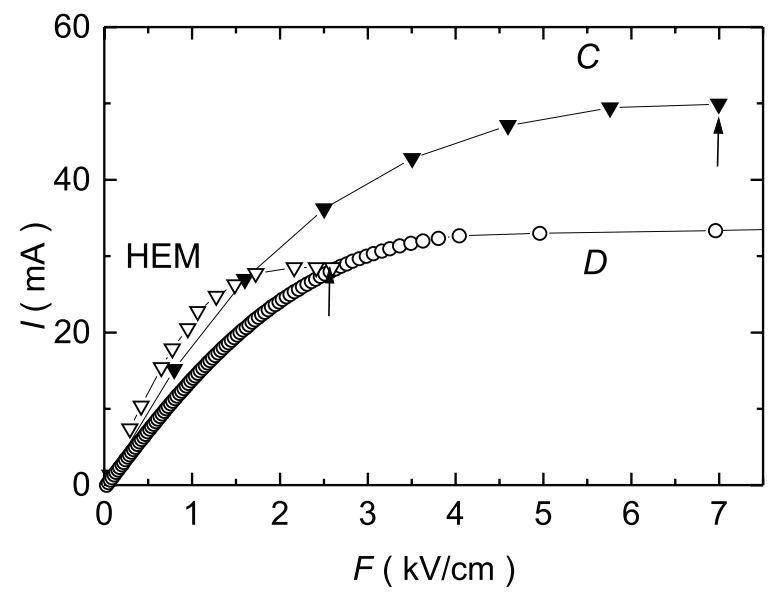

Fig. 2. Field dependences of the QW channel current in the modulation-doped heterostructures with different composition of QW and barrier layers: $\mathrm{Al}_{0.2} \mathrm{Ga}_{0.8} \mathrm{As} /$ $\mathrm{In}_{0.2} \mathrm{Ga}_{0.8} \mathrm{As} / \mathrm{GaAs}$ (sample C), $\mathrm{Al}_{0.15} \mathrm{Ga}_{0.85} \mathrm{As}_{\mathrm{In}} \mathrm{In}_{0.2} \mathrm{Ga}_{0.8} \mathrm{As} /$ $\mathrm{Al}_{0.15} \mathrm{Ga}_{0.85} \mathrm{As}$ (sample D) and $\mathrm{In}_{0.7} \mathrm{Al}_{0.3} \mathrm{As} / \mathrm{In}_{0.8} \mathrm{Ga}_{0.2} \mathrm{As}$ (sample HEM). The arrows show the threshold field $F_{\text {th }}$ for current instabilities.

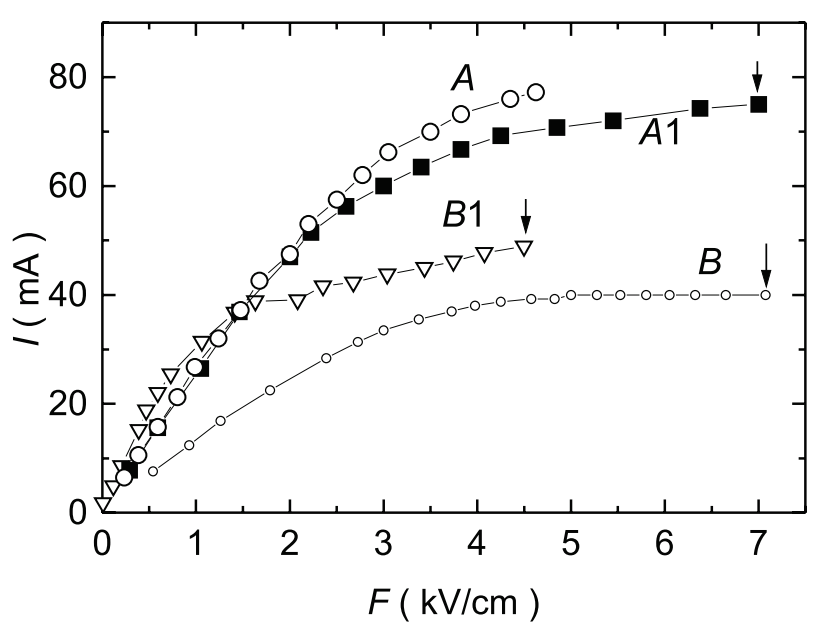

Fig. 3. Field dependences of the QW channel current in the $\operatorname{In}_{0.53} \mathrm{Ga}_{0.47}$ As QW for samples $A 1, B 1$ and $A, B$ with the InAs phonon walls and without them, respectively. The arrows show the threshold field $F_{\text {th }}$ for current instabilities. 
long $(100 \mu \mathrm{m})$ samples. A large decrease of the electron mobility by a factor of 1.5-2.0 with increasing electric field in the range of $1-4 \mathrm{kV} / \mathrm{cm}$ is experimentally observed. However, at fields up to $4 \mathrm{kV} / \mathrm{cm}$, the mobility in samples $A 1$ and $B 1$ with InAs inserts, as well as in sample HEM with increased InAs content remains higher than that in the structures without the InAs inserts. The experimental values of the saturated drift velocities in the samples are shown in Tables 1 and 2. In samples HEM, $C, D, A$ and $A 1$, the observed saturated drift velocity is $v_{\text {sat }} \approx(0.7-1.9) \cdot 10^{7} \mathrm{~cm} / \mathrm{s}$ and it does not exceed $v_{\text {sat }}=2.5 \cdot 10^{7} \mathrm{~cm} / \mathrm{s}$ estimated for a bulk InGaAs [6]. However, the saturated drift velocity in samples $B$ and $B 1$ (with GaAs inserts in the QW (see Fig. 1)) achieves $v_{\text {sat }}=2.5 \cdot 10^{7} \mathrm{~cm} / \mathrm{s}$. Therefore, thin GaAs inserts in the InGaAs QW are useful tools for enhancement of maximal (saturated) drift velocity.

Due to a decrease in the mobility, the field dependence of the drift velocity is sublinear and has a tendency to be saturated at electric fields lower than the threshold field for current instabilities.

Figure 4 demonstrates the field dependence of the electron density obtained from the magnetoresistance measurements, $n_{\mathrm{s} B}(F)$, for samples HEM, $B 1$ and $B$. The contribution of the change in the electron density in sample $B$ to the field dependence of the current along the QW channel is minor. However, in sample HEM, the electron density decreases by a factor of 1.5, when the electric field increases

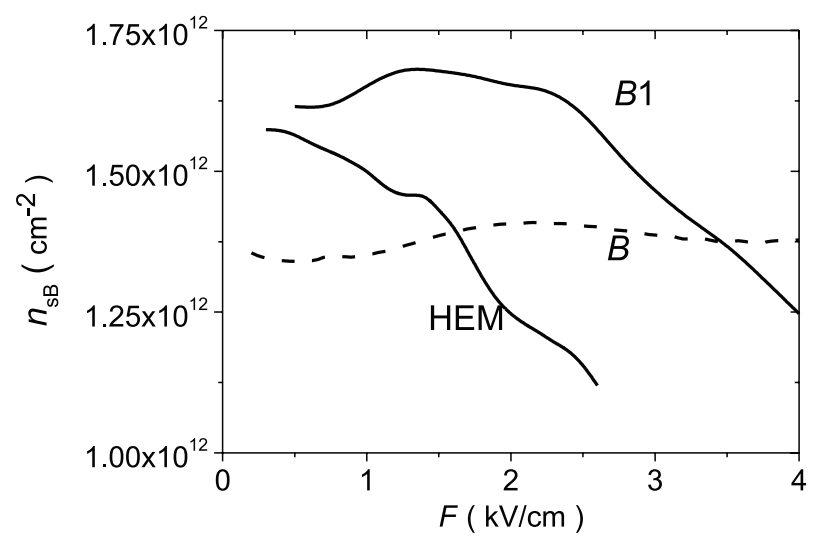

Fig. 4. Field dependences of electron density $n_{\mathrm{sB}}$ in the InGaAs QW for samples HEM, $B 1$ and $B$. up to $2.5 \mathrm{kV} / \mathrm{cm}$ (see Fig. 4). This leads to the current saturation in sample HEM at low $(2 \mathrm{kV} / \mathrm{cm})$ electric field (see Fig. 2). A great decrease of the density takes place at $F=2-4 \mathrm{kV} / \mathrm{cm}$ in sample $B 1$ with two InAs barrier layers (inserts). We assume that in a modulation-doped structure, the change of field $F_{\perp}$ perpendicular to a QW plane is responsible for the change in the electron density in the QW channel [14].

It is worth to note that at low electric field, the electron density $n_{\mathrm{s} B}$ in the samples with the deposited ohmic contacts significantly differs from the electron density in homogeneous materials, $n_{\mathrm{s} 0}$ (see Table 2). We expect that a strong perturbation of the $F_{1}$, which depends on fabrication technique of sample contacts and also on sample structure, leads to a large change in the QW channel electron conductivity.

\section{Conclusions}

The effective tools for decreasing the electronphonon scattering rate (and, therefore, for increasing the electron mobility) in modulation-doped $\mathrm{In}_{0.52} \mathrm{Al}_{0.48} \mathrm{As} / \mathrm{In}_{0.53} \mathrm{Ga}_{0.47} \mathrm{As}$ and $\mathrm{AlGaAs} / \mathrm{InGaAs}$ structures are demonstrated. The first one is the regulation of composition in the QW barrier layer semiconductor. The second one is the insertion of InAs phonon walls into the QW layer. Using both tools allows us to achieve a significant increase in the electron mobility in the studied structures as compared with the mobility in the conventional HEMT structures: $\operatorname{In}_{0.53} \mathrm{Ga}_{0.47} \mathrm{As} / \mathrm{In}_{0.52} \mathrm{Al}_{0.48} \mathrm{As}$ and $\mathrm{Al}_{0.15} \mathrm{Ga}_{0.85} \mathrm{As} / \mathrm{In}_{0.2} \mathrm{Ga}_{0.8} \mathrm{As}$. It is found that the saturation of high-field drift velocity in modulation-doped structures takes place at the electric field lower than the threshold field for current instabilities.

\section{References}

[1] B.K. Ridley, Phys. Rev. B 39, 5282 (1989).

[2] R. Haupt and L. Wendler, Phys. Rev. B 44, 1850 (1991).

[3] J. Požela, A. Namajūnas, K. Požela, and V. Jucienė, J. Appl. Phys. 81, 1775 (1997).

[4] M.A. Stroscio and M. Dutta, Phonons in Nanostructures (Cambridge University Press, Cambridge, 2001).

[5] J. Požela, K. Požela, and V. Jucienè, Semiconductors 41, 1074 (2007) [Fiz. Tekh. Poluprovodn. 41, 1093 (2007), in Russian]. 
[6] J. Požela, K. Požela, R. Raguotis, and V. Jucienė, Semiconductors 45, 761 (2011) [Fiz. Tekh. Poluprovodn. 45, 778 (2011), in Russian].

[7] D.R. Anderson, N.A. Zakhleniuk, M. Babiker, B.K. Ridley, and C.R. Bennet, Phys. Rev. B 63, 245313 (2001).

[8] V.A. Kulbachinskii, I.S. Vasil'evskii, R.A. Lunin, G. Galistu, A. de Visser, G.B. Galiev, S.S. Shirokov, and V.G. Mokerov, Semicond. Sci. Technol. 22, 222 (2007).

[9] G.B. Galiev, I.S. Vasil'evskii, E.A. Klimov, V.G. Mokerov, and A.A. Cherechukin, Semiconductors 40, 1445 (2006) [Fiz. Tekh. Poluprovodn. 40, 1479 (2006), in Russian].

[10]I.S. Vasil'evskii, G.B. Galiev, E.A. Klimov, V.G. Mokerov, S.S. Shirokov, R.M. Imamov, and I.A.Subbotin, Semiconductors 42, 1084 (2008) [Fiz. Tekh. Poluprovodn. 42, 1102 (2008), in Russian].

[11] V.G. Mokerov, I.S. Vasil'evskii, G.B. Galiev, J. Požela, K. Požela, A. Sužiedèlis, V. Jucienè, and Č. Paškevič, Semiconductors 43, 1084 (2009) [Fiz. Tekh. Poluprovodn. 43, 1102 (2009), in Russian].

[12]J. Požela, K. Požela, A. Shkolnik, A. Sužiedèlis, V. Juciene, S. Mikhrin, and V. Mikhrin, Phys. Status Solidi C 6, 2713 (2009).

[13] I.S.Vasil'evskii, G.B. Galiev, Yu. A. Matveev, E.A. Klimov, J. Požela, K. Požela, A. Sužiedèlis, Č. Paškevič, and V. Juciené, Semiconductors 44, 898 (2010) [Fiz. Tekh. Poluprovodn. 44, 928 (2010), in Russian].

[14] J. Požela, K. Požela, V. Jucienè, and A. Shkolnik, Semicond. Sci. Technol. 26, 014025 (2011).

[15] J. Požela, K. Požela, V. Jucienè, I.S. Vasil'evskii, G.B. Galiev, E.A. Klimov, A. Sužiedèlis, N. Žurauskienè, V. Stankevič, S. Keršulis, and Č. Paškevič, Acta Phys. Pol. A 119, 170 (2011).

[16]K. Onda, A. Fujihara, A. Vakejima, E. Mizuki, T. Nakayama, H. Miyamoto, Y. Ando, and M. Kanamori, IEEE Electron Dev. Lett. 19, 300 (1998).

[17]H. Zhao, Y.-T. Chen, J.H. Yum, Y. Wang, F. Zhou, F. Xue, and J.C. Lee, Appl. Phys. Lett. 96, 102101 (2010).

[18] M. Dyakonov and M. Shur, Phys. Rev. Lett. 71, 2465 (1993).

[19] N. Dyakonova, F. Teppe, J. Łusakowski, W. Knap, M. Levinshtein, A.P. Dmitriev, M.S. Shur, S. Bollaert, and A. Cappy, J. Appl. Phys. 97, 114313 (2005).

[20]X. Wallart, B. Pinsard, and F. Mollot, J. Appl. Phys. 97, 053706 (2005).

[21] V. Drouot, M. Gendry, C. Santinelli, P. Victorovitch, G. Hollinger, S. Elleuch, and J.-L. Pelouard, J. Appl. Phys. 77, 1810 (1995).

[22] M. Tacano, Y. Sugiyama, Y. Takeuchi, and Y. Ueno, J. Electron. Mater. 20, 1081 (1991).

\title{
ELEKTRONŲ PERNAŠA MODULIUOTAI LEGIRUOTUOSE InAlAs/InGaAs/InAlAs ir AlGaAs/InGaAs/AlGaAs DARINIUOSE
}

\author{
J. Požela ${ }^{\text {a }}$, K. Požela ${ }^{\text {a }}$ V. Juciené ${ }^{\text {a }}$, A. Sužiedèlis ${ }^{\text {a }}$, N.Žurauskienè ${ }^{\text {a }}$, A. S. Shkolnik ${ }^{\text {b }}$ \\ ${ }^{a}$ Fiziniu ir technologijos mokslu centro Puslaidininkiu fizikos institutas, Vilnius, Lietuva \\ b Innolume GmbH, Dortmundas, Vokietija
}

\section{Santrauka}

Tiriamos ir apžvelgiamos elektronų judrio ir dreifo greičio stipriuose elektriniuose laukuose padidinimo galimybès moduliuotai legiruotuc InAlAs/InGaAs ir AlGaAs/InGaAs darinių kvantinèse duobèse, reguliuojant elektronų sąveiką su paviršiniais fononais. Judris itin padidejo naujame metamorfiniame $\mathrm{In}_{0.7} \mathrm{Al}_{0.3} \mathrm{As} /$ $\mathrm{In}_{0.8} \mathrm{Ga}_{0.2} \mathrm{As}$ darinyje su didele InAs moline dalimi InAlAs barjero sluoksnyje, taip pat $\mathrm{Al}_{x} \mathrm{Ga}_{1-x} \mathrm{As} / \mathrm{In}_{0.2} \mathrm{Ga}_{0.8} \mathrm{As}$ darinyje su maža InAs dalimi AlGaAs barjero sluoksnyje. Taip pat judris padidejo, kai ploni InAs sluoksniai yra itterpti i $\operatorname{In}_{0,52} \mathrm{Al}_{0,48} \mathrm{As} / \mathrm{In}_{0,53} \mathrm{Ga}_{0,47}$ As kvantinę duobę. Elektronų dreifo greitis issisotina $1,5-5 \mathrm{kV} / \mathrm{cm}$ stiprio elektriniuose laukuose ir jo maksimali verte yra $2,5 \cdot 10^{7} \mathrm{~cm} / \mathrm{s}$ InGaAs kvantinèse duobèse, turinčiose plonus InAs ir GaAs intarpus. 